\title{
The socio-cultural functions of indigenous languages in teaching theology
}

\author{
Resane, Kelebogile T \\ University of the Free State \\ resanekt@ufs.ac.za
}

\begin{abstract}
This article aims to show that indigenous knowledge systems are the reservoirs of useful knowledge for teaching theology, particularly indigenous languages. It argues that theological language is an identity marker, and an ideological tool. Indigenous languages have something to offer in teaching theology.

Language is a powerful force that forms national identity; and it contributes towards national unity. It is part of culture and it explains the abstracts through figures of speech. These figures of speech or metaphors are mostly comprehensible when viewed from indigenous languages' point. Opportunities must be created for the space of the acquisition of these languages as a way of exploring and discovering the meaning of the texts. It is therefore recommended that the linguistic competence and performance be mastered for catching the metaphorical contents of the texts. Teaching theology does not only require gratis dictum but also expertise in language technical application such as code-switching, sandwich technique, mother-tongue mirroring, and backchaining.
\end{abstract}

Keywords

Language, Theology, Culture, Teaching, Ideology, Identity

\section{Introduction}

Language is the powerful tool of communication in the world. Globalization demands workforce population to communicate in multiple languages. The world network in areas of trade, tourism, international relations, technology, media, and sciences put pressures for multilingual abilities. 'Language is a crucial means of gaining access to important knowledge and skills. It is the key to cognitive development and it can promote or impede scholastic success' (Le Roux 1993:146). It is easy to ignore or bypass the 
power of the language in formulating human worldviews and perceptions. Mellor (1989:6) brings this to attention that:

Language is central to any group as a means of communicating ideas and instructions, though each language by its nature has an important influence on how ideas, concepts, values, and imagery are expressed. Language, culture, and perception are intimately intertwined. It is thus not surprising that language has been a key element contributing to a sense of national identity.

The study of religion and theology is no different. Conservatively, theologians, especially those majoring with textual studies are forced to study Hebrew and Aramaic in order to master the Old Testament; Greek and Latin in order to master the New Testament and patristics. In Africa languages and dialects are in thousands; and most of them relate to these ancient text languages to some degrees. Some of them carry grammar and vocabulary that defines the biblical concepts better than the English language. These languages and dialects can assist in articulating beliefs and faith. The hidden meanings embedded in the ancient languages are helpful in clarifying religious mysteries. Ayres (in Crisp \& Sanders 2014:100) points out that:

Doctrinal formulae enable articulation of what is revealed in rational terms, and they enable a certain clarity about and defence of what is revealed; but this does not mean that the divine mystery is a fog to be cleared, and the same formulae may also shape our ever deeper entry into that as it is revealed through the text of Scripture.

\section{Culture and language in the context of theology}

South Africa is historically known for the anomaly of linguistic stratification. The indigenous languages suffered socio-cultural setbacks through marginalisation and divide et empera (divide and rule), consequently relegated to the periphery of the public domain. The so-called official language(s) were elevated to superior means of communication. The South African indigenous languages are marked briller par son absence in the academia. This led to the creation of the huge gap where these languages could not grasp their eloquence in interpretation of theological concepts. The social identities also suffered enormously in this regard. 
The fact remains that 'Language is one carrier of the cultural symbols and meanings of groups and so plays a crucial role in constructing social identities' (Coetzee \& Roux 2000:339). The same notion is carried by the English theologian, Ted Peters, that 'Language is the decisive power that catapults us up and out of mere biological existence and into the realm of culture, history, value, meaning, and intense relationships' (2000:150).

One of the challenges of black students is to study theology in a foreign or second language. The marginalisation of indigenous languages carrying wealth in matters of concepts, symbols, interpretation etc. denied the black population groups a place in the articulation of Christian faith's self-understanding; and also undermined the role of these languages as purveyors of wider culture (Coetzee \& Roux 2000:339).

To demonstrate this point, there is a falsified notion in the Afrikaans speaking universities of generalising all the non-Afrikaans speaking as English while the majority are actually not. This is a misconception in the academia that needs to be rectified. The same falsified notion applies to teaching theology. If the current university students received most of their basic education in their mother tongue, this could help them to conceptualise theories taught in English at the university level. Black theology students exposed to English fail to indigenize and conceptualise theology in their indigenous language, hence, the current phenomenon of pastors and priests born and bred in our townships and villages preaching in English with an interpreter. Pedagogically, first language is central to student's socialisation and enculturation. Language 'affects the child's emotional development because linguistic expression transforms emotional experience into a communicable form. It affects the child's cognitive development because language anticipates and guides intellectual activity' (Le Roux 1994:137). Language is not a prison, but a key communication in the pastoral duties.

If a language lacks the terms to communicate what the original biblical languages convey, that lack does not open an unbridgeable chasm. Circumlocutions can skirt the difficulty, metaphors may be coined, and expressions may be borrowed from the biblical languages or other languages, and defined by their usage in the biblical context (Clowney 1995:180). 
Theology evolved out of a particular culture with its distinctive linguistics, vocabulary, and idiomatic expressions. The bottom line here is that language enhances our understanding of Scriptures. 'Cultural and linguistic diversity enriches our understanding of God's revelation in both nature and Scripture' (Clowney 1995:180). One of the prevalent theological debates is how to unravel the embodied theology towards epistemological reality. Disembodied theology is theology that is detached from the cares, desires, and interests of human beings. It is the theology that is removed from material, political, or cultural context (Woodhead 1998). In other words, how to move theology as a foreign language to embodied theology that makes sense and addresses the context in which a student finds himself. This is expressed by Woodhead (1998:44-47) that 'by teaching embodied theology, theology comes to seem less foreign, because it becomes clear how it is bound up with matters of obvious, immediate, and material importance.' Theology students studying in English, without the basics of the indigenous language, find it difficult to conceptualise and indigenise the Anglo-centred socio-cultural heritage of fables, legends, metaphors, proverbs, songs and poems that form part of the English cultural background. This was not part of their cognitive development. All these become abstracts that obstruct theological understanding and insights. Le Roux (1994:158) asserts that 'the role played by this kind of cultural heritage at all levels of schooling and in all school subjects cannot be underestimated.'

The reality of relational context cannot be short-circuited. Taylor et al (2013:7) use the concept 'relational context' to refer to 'a given social situation where the individual interacts with other persons in a particular social capacity responding to particular expectations.' Language becomes a central tool for this social interaction, because the role of this language within the setting is to articulate and express people's self-understanding and cultural inclinations. Theologians engaged or committed to sociocultural dialogues that involve church and society, academy and church, academy and society etc. need to prioritize the language - not just its acquisition but also its relevance within the context. Theology's technical language should be demystified in order to unravel the complexities that may hinder understandings of issues at stake. This is done and can be achieved 'without undermining the thought that our knowledge and our 
experiences are always expressed in and given to us through language' (Hermann in Gregersen \& Huyssteen 1998:137). This notion is further developed and elaborated by Gregersen that 'theology is a far more contextsensitive discipline since theological content cannot be divorced from cultural context' (1998:185).

Language gives meaning to concepts, especially when one excels in the knowledge of the historical roots of it. History has proved that students who acquire sufficient proficiency in mother-tongue enjoy 'an increased awareness of the nature of language, greater flexibility in understanding the arbitrary associates of words and referents and increased sensitivity to the interpersonal cues of language use' (McGroarty in Scarcella 1990:55). There are certain biblical concepts or words that explain the texts far much than the language of instruction such as English. It becomes clearer for one to apply Ubuntu/Botho concept to understand the communion ecclesiology of the apostolic church in the Book of Acts. It makes some sense for the Indian kutum (large house under patriarchal leader who makes decision for the whole household) in explaining the household conversions in the early church. The letsema concept in the Setswana culture best explains the biblical principle of 'one another' whereby mutual caring support become the marks of ecclesia.

\section{Theological language and identity}

The individual member of any community expresses his or her worldview through language. A human being is a linguistic being. Ford, Quash and Soskice (2011) point out that this is expressed by philosophers such as Franz Rosenzweig (philosophy of speaking thinking) and Martin Buber (speaking being). They continue to highlight that 'For both Buber and Rosenzweig the human being was essentially a 'speaking' being' (2011:174). It is through the language that a human being is informed of his or her history, traditions, and life in general. 'Languages embody distinctive ways of experiencing the world and so play a crucial role in defining the experiences of a community as their particular experiences. Since language is a determinant of a particular outlook, it is one significant factor that shapes a way of life' (Coetzee \& Roux 2000:278). Language as a social possession and phenomenon gives humanity its identity. Humanity and individuality interacts linguistically for obtaining identity. 
We are brought into full human being by those others who bring us into language as much as by those who bear us physically in their wombs. Even our most private thoughts are always already framed and formed by the language we have with others, though not fully determined by it (Ford, Quash \& Soskice 2011:174).

Language contributes enormously to the national identity. It assists with identifying one's heritage and philosophy of life. The Catholic scholar, Walter Kasper correctly sees that 'Human language especially shows that human subjectivity exists only in intersubjectivity, in men's existence with one another, as orientated to one another and of one another' (1976:222). Both developed and developing nations attest to the fact that language is a uniting national force that brings people together to submit under one particular structural authority. It is the language that gave Apostle Peter an identity that he was associated with Jesus: 'Surely you are one of them, for your accent gives you away' (Mt 26:73). Whenever scientists, including theologians, come together to dialogue, debate, or discuss, technical language stands out; depending on their expertise and field of specialisation. Language is commonly used as an indicator of academic membership. This is from the ancient times to use language to assert one's identity, philosophy, and convictions. Torrance (1965:19) drives this point home that 'Greeks employed myths, artistic forms, to express the transcendent realities of the intelligible world which they called the forms, and could think of God only through eidetic images.' The philosophy had to be expressed artistically and linguistically to make sense of perceptions or worldview. Many African languages, and others around the world find identity through proverbial and idiomatic expressions in order to forge understanding. Theological education cannot be divorced from the linguistic expressions that finally will give a better understanding of theological constructs. It is through language that Christ is revealed and made known to humanity. In citing Fuchs (1964:208-9), Dulles (1987:81) captures the fact that 'This languageactivity is the mark of the community. The language of faith brings into language the gathering of faith and thereby Christ.' The same principle is attested by Ayres (in Crisp \& Sanders 2014:107) that 'The language of faith, then, draws us toward the mystery of God and to the mystery of God's presence in and to the Christian.' 
The unity of the church cannot be assailed because of languages. This phenomenon is prevalent in the current South Africa where ecclesiastical structures are separated based on socio cultural reasons, especially language. Language is used to divide instead of uniting. The caution is clear:

We may need to divide for practicality over language. But, as much as we can, let us not divide our churches for other cultural reasons. The gospel is displayed when those whom the world understands as having no reasons for commonality - who perhaps even have reasons for animosity - stand together united in love (Phillips, Ryken \& Dever 2004:90).

Language is an inherent part of the Christian tradition. It is through language that ecclesiastical dogmatic and ethical knowledge is conveyed. It is therefore understood when community or church is organised around language. This should be done with caution so that language is not used to deny people access to the community or church membership. It is for this reason that Fretheim \& Froehlich (1998:49) emphasizes the fact that 'when faith goes out to meet the challenges of the day, it must come home from all its excursions to the matrix - the language of the Bible.'

\section{Theological language and ideology}

For theological articulation, a theologian needs to be both a philologist and a linguist. A philologist is concerned with the historical development of languages utilised and applied in written texts within the context of literature and culture. On the other hand, a linguist's main focus is the analysing and application of spoken languages. There is inevitably a symbiosis of beliefs and socio-cultural interactions. It is true that 'language ideologies link the implicit as well as explicit assumptions people have about a language or language in general to their social experience and political as well as economic interests.' (See: https://en.wikipedia.org/wiki/ Language_ideology). Many scholars have argued that ideology plays a role in shaping and influencing linguistic structures and speech forms. Michael Silverstein (In Clyne, Hanks \& Hofbauer 1979: 193-248), for example, sees speakers' awareness of language and their rationalizations of its structure and use as critical factors that often shape the evolution of a language's structure. This notion is also supported by Alan Rumsey (1990:346-361) 
who sees linguistic ideologies as playing a role in shaping the structure of a language, describing a circular process of reciprocal influence where a language's structure conditions the ideologies that affect it, which in turn reinforce and expand this structure, altering the language 'in the name of making it more like itself.'

Approaches to language ideology explore the capacity for language to be used as strategies for maintaining social supremacy and dominance. These strategies are highlighted by Woodland and Schieffelin (1994:55) as studies of 'some aspects of representation and social cognition, with particular social origins or functional and formal characteristics.' It is clear then that the articulation of ideology is essential to prevent misconceptions of meaning and intentions between disciplines of studies, and provides a link between socio-cultural and linguistic processes in contact situation. Theological studies in their uniqueness of history and metanorms should follow some form of apodictic law in order to safeguard and preserve ideologies that are consonant with theological dogma and Christian convictions. The fundamental fact is that 'One must learn the language of faith before one can know enough about its message knowingly to reject it and thus be lost' (Lindbeck 1984:59). The cosmic order that evolved through hermeneutics and homiletics should be preserved as both paradosis and catechesis to be cherished. Ideology must be legitimized, lest Coetzee and Roux's warning become a reality that 'the study of ideology is a study of systematic distorted communication' (2000:350). In a nutshell, just as in natural sciences, studying, teaching, and learning theology, propositions must be formulated from the observations or data by interpreting them in a framework or paradigm. This framework depends largely on the axioms, assumptions or premises of the scientist (Sarfati 2004:41). This harmonizes well with Archer (2009:216) that 'the language (langue) is a system of signs and laws regulating grammar and syntax - a sort of 'canon' establishing guidelines for meaning.' The approach is in line with Kuhn's (1996) thinking that in many fields the data is interpreted according to the ruling paradigm, and anomalies always discarded or explained away.

Language should not be used for the destruction of the pillars of faith. Theologians are called upon to watch the language flux that demean the unshakable and unquestionable creeds. The truth is that theologians must hold on to the ideology of standardisation, by which they must promote 
the notion of indigenous languages alive in the public mind. This calls for proper concern for clarity and effectiveness in communication that may come through signs and symbols (semiotics). This is an indisputable fact because 'semiotics emphasizes the transaction of meaning between texts and readers, thus involving the reader in the production of meaning in order to complete the communication event' (Archer 2009:216). Theologians' prescriptions should focus more on public and written styles than on casual speech. This is the bedrock where the richness of languages lie. The application and understanding of semiotics agree that 'Arguments that one language or dialect is linguistically superior to another are generally very difficult to sustain' (Milroy \& Milroy 1991:15). Ideologies fester human minds all the time, and scholars linguistically articulate these ideologies. The same is expected of scholars in the field of theology. Ayres (in Crisp \& Sanders 2014:100) ably calls this to attention:

Clarity in and care about our language should surely be valued by those to whom God has given minds... such arguments should always be viewed as also parasitic and as gateways back to the terms and statements and passages that stimulated their appearance. Remembering that our formulae are signposts back to the particular patchworks of texts, to particular configurations of scriptural invitations, may help to order all our speech and thinking appropriately toward God, toward a place where rational investigation must draw us only toward mystery.

\section{Contribution of indigenous languages to theology}

It is clear that there is no such a thing as superior language when kerygma is in operation. It is through the medium of a language that proclamation is applied. John Macquarrie (1997:10) reminds us that 'Gospel is preaching or proclamation; it is a first order language which is unselfconscious, a language in which faith speaks in order to awaken faith through the transmission of the good news on which faith has been founded.' The indigenous languages are rich with metaphors that enhance the message of the Gospel that brings liberation to the hearers. Moltmann (1989:215) is spot on to the fact that 'The Christian proclamation is the messianic message of joy and as such it is the language of liberation.' This calls for a big challenge to those involved in cross-cultural ministries. The 
expansion and the growth of their missiological efforts is enhanced by their acquisition of the indigenous language they interact and interface with. The leadership expert, Samuel Chand states without any reservation that 'For churches to grow, the natives have to adapt to the immigrants' language and needs rather than forcing immigrants to make changes to fit in' (2002:43). Language acts through forms of mental representations to produce mechanism of power. It is acknowledged, noticed, and objectified as a sign or symbols that has the energy to transform into an agency of power.

The example below is ex uno disce omnes - from one example in Setswana and isiZulu, we learn a general principle as it applies to all other indigenous languages. One of the biblical doctrines which is also a soteriological benefit is peace. In Greek it is eirénè. It carries the meaning of the lack of disturbance, or 'the absence of hostile feelings' (Kittel \& Friedrich 1985:207). In Setswana this word is kagiso, from the root verb, aga, which means to build. The interpretation by the declension of the root verb aga to kagiso, the meaning becomes building with or building together. In a broader sense the word refers to harmony or synergy whereby every part is in agreement, in synchrony. The Pauline dictum that 'since we have been justified through faith, we have peace with God through our Lord Jesus Christ' (Rom 5:1) in the Setswana context of the word kagiso means we are building together with God in and towards harmony. We, together with God are in agreement. We, together are partners with one goal in mind. You can imagine the teacher in the New Testament class dealing with the textual studies of Romans explaining this text from this language, the impact and revelation it can bring to students.

The word 'peace' in the Zulu language (ukuthula) has literal meaning of calmness and quietness. It still makes sense in the biblical reference that peace with God means calmness or serenity with God. When God and believer are together or in harmony, there is no conflict or disagreement. No knotty issues involved between the two. This reinforces the fact that 'learners come to understand things (make sense of their experiences) through language. It is important to all aspects of learning in all learning situations' (Killen 2000: xxv). Theology students learning in foreign language are to constantly appeal to their indigenous languages in order to capture the original meaning in some fresh understanding. In some 
instances, discoveries are made of the shortfall of English language in translating some terms, metaphors, or proverbial expressions; that may be better captured by the indigenous languages. Like in all languages of the world, the indigenous languages of South Africa require linguistic competence and performance. Linguistic competence is the knowledge and mastery of the rules governing language use. Linguistic performance is the speaker's ability to use language when interacting with others (Mwamwenda 1995: 161-171). Language in theology cannot be used as hapax legomenon (solitary instance), but as continuous research and discoveries of wealth of meaning in the ancient textual languages (Hebrew, Aramaic, Greek and Latin) as well as in indigenous languages. Teachers of theology must realise this as the necessary ignotum per ignotius - the hidden knowledge that still needs to be exposed. There is no doubt then that 'For effective teaching and learning to take place, both communication skills (BICS) and academic language proficiency (CALP) are important' (Lindeque, Gawe \& Vandeyar in Jacobs, Vakalisa \& Gawe 2015:106).

\section{The application of languages in teaching theology}

There is lack of expertise in language technical application in current theology teaching. Teaching theology does not only require gratis dictum (mere assertion) but also expertise in language technical application. Theology, like any social science necessitates the use of academic terminology. The theology students have to know the theology-specific meaning of its technical words. 'A technical term is a word which, when used in a particular subject, has a specific meaning' (Le Roux 1993:164). For the teacher, the mandate is clear: 'You cannot avoid the fact that every subject has its jargon, but you cannot expect learners to understand the ideas you are presenting if the things you say confuse them. Therefore, you must help the learners master the language of your subject as they strive to understand its content' (Killen 2000:25). Teaching or writing theology needs the skills such as:

\section{Code Switching}

This is a technique of changing between languages at some point in a sentence or utterance. This is common among the language learners and multilinguals. Code-switching also accelerates understanding in learning, 
hence for students to succeed, 'teachers have a responsibility both to support mother tongue and to develop English proficiency' (Lindeque, Gawe \& Vandeyar in Jacobs, Vakalisa \& Gawe 2015:106). Students like to code switch regardless of pedagogics' discouragement of it. It is powerful in conversational settings and should be encouraged as a teaching strategy, especially during the interactive learning processes. This practice shows the importance of 'understanding the value of mother-tongue education, while also appreciating the value of English.' (Vale 2016:28)

\section{Sandwich technique}

This is an oral insertion of an idiomatic translation in the mother tongue between an unknown phrase in the learned language and its repletion. It is intended to convey meaning as rapidly and completely as possible. Reading an English text with humanness estro sandwiched with idiomatic expression 'motho ke motho ka batho' expressing 'ubuntu', the meaning of the concept heightens towards inspiration.

\section{Mother tongue mirroring}

This is adaptation of the time-honoured technique of literal translation or word-for-word translation for pedagogical purposes. The main purpose is to construct foreign concepts to be salient and transparent and make them void of technical jargon of grammatical analysis. It is the indigenous knowledge systems that enhance learning by demystifying the learning contents and processes. Didactically, it can be used to the extent that it remains intelligible to the student, unless it is combined with a normal idiomatic translation. This is expressed by Higgs and Van Niekerk (2002:42) that;

If teachers in an African context, could start with the indigenous knowledge systems which provide the framework for their learners' initial experiences, then learners would be encouraged to draw on their cultural practices and daily experiences as they negotiate new situations. 


\section{Back-chaining}

This technique is used in teaching oral language skills, especially with polysyllabic or difficult words. This is only used orally, not for writing. It stimulates the minds of students to recall the technical word to be used.

All these techniques reinforce and enhance socio-cultural understanding of theological teaching and learning. When cooperative learning technique is engaged in a classroom situation, these techniques will be employed to bring points home and to ensure all are on board and on track.

\section{Conclusion}

Language in theological education enhances socio-cultural interactions. It is binding force that facilitates understanding and unity beyond the teaching space. It contributes to a sense of national unity. The study of ancient languages of the Bible (Hebrew, Aramaic, Greek and Latin) reinforces the understanding of the textual studies. Many African languages to some degrees, relate to these languages; and make understanding far much better. The Biblical grammar, beliefs, and dogmatic formulations can be better articulated if one is conversant or knowledgeable of indigenous language (s).

The demise and peril of indigenous languages contributes to privation of comprehension of theological assertions within socio-cultural contexts. This clasps creativity and innovation in articulating theological concepts in the most comprehensible ways. The theologian's identity is also affected by the shortage of the utilisation or application of language in theological dialogues and discussions. Language is a determinant of a particular worldview, hence it shapes mental attitudes towards life. As a social possession and phenomenon, it gives humanity its identity. Humanity and individuality interacts linguistically for obtaining identity. It is an irrefutable fact that learning theology as learning any social or natural science, does not occur in isolation. It is socially constructed; and possesses both sociological and psychological implications (Jordan, Carlile \& Stack 2009:68-81).

Ideology plays a role in shaping and influencing linguistic structures and speech forms. The awareness of language and its rationalizations often 
shape the evolution of its structure. This enables a clear articulation of ideology essential to prevent misconceptions of meaning and intentions between disciplines of studies, and provides a link between socio-cultural and linguistic processes in contact situation. Theological metanorms should follow some apodictic law in order to safeguard and preserve ideologies that are consonant with theological dogma and Christian convictions. Language should not be used for the destruction of the pillars of faith. The ideology of standardisation should be endeavored in order to remain within the mainstream creedal confessions. This should be done in order to promote indigenous languages in the public mind. This calls for proper concern for clarity and effectiveness in communication that may come through signs and symbols (semiotics).

The indigenous languages can be utilized in order to enhance the meaning of theological mysteries embedded in the biblical texts. Opportunities must be created for the space of the acquisition of these languages as a way of digging deep into the texts. It is also recommended that the linguistic competence and performance be mastered for catching the metaphorical contents of the texts. The application of the language becomes comprehensible if one knows the techniques of code-switching, sandwich, mirroring, and backchaining. This calls for reculer pour mieux sauter - the act of retreating in order to advance the deeper and better theological understanding in socio-cultural contexts. Bourdieu (1986), the French education sociologist, coined the term le capital culturel - 'cultural capital' by which he explains that having certain cultural knowledge gives one an advantage which comes along with status and power. It promotes social mobility beyond economic means and acts as a social relation within a system of exchange that includes the accumulated cultural understanding that confers power and status; hence possessing pros and cons. The contemporary theologian must be cautious not to produce the theologically elite graduate who cannot be of contribution to human empowerment - socio-culturally or spiritually. 


\section{Bibliography}

Archer, KJ 2009. A Pentecostal Hermeneutic: Spirit, Scripture and Community. Cleveland: CPT Press.

Bourdieu, P 1986. 'The Forms of Capital'. In J Richardson (Ed). Handbook of Theory and Research for the Sociology of Education. New York: Greenwood Press.

Chand, SR \& Murphey, C 2002. Futuring: Leading Your Church Into Tomorrow. Highland Park: Mall Publishing Company.

Clowney, EP 1995. The Church: Contours of Christian Theology. Downers Grove: InterVarsity Press.

Clyne, P, Hanks W \& Hofbauer C (Eds). 1979. 'Language Structure and Linguistic Ideology.' The Elements (pp. 193-248). Chicago: Chicago Linguistic Society.

Coetzee, PH \& Roux APJ 1998. Philosophy from Africa: A Text with Readings. Oxford University Press, Oxford.

Crisp, OD \& Sanders F (Eds). 2014. Advancing Trinitarian Theology: Explorations in Constructive Dogmatics. Grand Rapids: Zondervan.

Dulles, A 1987. Models of the Church (Expanded Edition). New York: Doubleday.

Ford, DF, Quash, B \& Soskice, JM 2011. Fields of Faith: Theology and Religious Studies for the Twenty-first Century. Cape Town: Cambridge University Press.

Fretheim, TE \& Froehlich K 1998. The Bible as Word of God: In a Postmodern Age. Eugene: Wipf and Stock Publishers.

Gregersen, NH \& Huyssteen, JW (Eds). 1998. Rethinking Theology and Science: Six Models for the Current Dialogue. Brand Rapids: WB Eerdmans Publishing Company.

Higgs, P \& Van Niekerk, MP. 'The Programme for Indigenous Knowledge Systems (IKS) and Higher Educational Discourse in South Africa:

A Critical Reflection'. South African Journal of Education, 2002 Vol 16 (3). Pp 38-49. 
Jacobs, M, Vakalisa, NCG, Gawe, N 2015. Teaching-Learning Dynamics $\left(4^{\text {th }} \mathrm{Ed}\right)$. Cape Town: Pearson Education.

Jordan, A Carlile, O. \& Stack, A 2009. Approaches to Learning: A Guide for Teachers. Berkshire: McGraw-Hill/Open University Press.

Kasper, W 1985. Jesus the Christ. Wellwood/Mahwah: Burns and Oates/ Paulist Press.

Killen, R 2000. Teaching Strategies for Outcomes-Based Education. Landsdowne: Juta \& Co.

Kittel, G \& Friedrich, G (Eds). 1985. Theological Dictionary of the New Testament: Abridged in One Volume. Grand Rapids: WB. Eerdmans Publishing Company.

Kuhn, TS 1996. The Structure of Scientific Revolutions ( ${ }^{\text {rd }}$ Ed). Chicago: University of Chicago Press.

Le Roux, J 1993. The Black Child in Crisis: A Socio-Educational Perspective (Vol 1). Pretoria: Van Schaik.

- 1994. The Black Child in Crisis: A Socio-Educational Perspective (Vol 2). Pretoria: Van Schaik.

Lindbeck, GA 1984. The Nature of Doctrine: Religion and Theology in a Postliberal Age. Louisville: Westminster John Knox Press.

Macquarrie, J 1997. Jesus Christ in Modern Thought. London: SCM Press/ Philadelphia, Trinity Press International.

Mellor, EH 1989. Nation, State, and Territory: A Political Geography. London/New York Routledge.

Milroy, J \& Milroy L 1991. Authority in Language: Investigating Language Prescription and Standardisation (2nd Ed). London/New York: Routledge and London/New York: Keegan Paul.

Moltmann, J 1977. The Church in the Power of the Spirit. London: SCM Press.

Mwamwenda, TS 1996. Educational Psychology: An African Perspective (2nd Ed). Isando/Butterworth: Heinemann Publishers. 
Peters, T 2000. God - The World's Future: Systematic Theology for a New Era (2nd Ed). Minneapolis: Augsburg Fortress.

Phillips, RD; Ryken, PG \& Dever, ME 2004. The Church: One, Holy, Catholic, and Apostolic. Phillipsburg: P\&R Publishing Company.

Rumsey, A 1990. 'Wording, Meaning, and Linguistic Ideology'. American Anthropologist 92 (2): 346-361. doi:10.1525/aa.1990.92.2.02a00060.

Sarfati, J 2004. Refuting Compromise: A Biblical and Scientific Refutation of 'Progressive Creationism (Billions of Years) as Popularized by Astronomer, Hugh Ross. Green Forest Master Books.

Scarcella, R 1990. Teaching Language Minority Students in the Multicultural Classroom. New Jersey: Prentice-Hall.

Taylor, F et al 2013. 'Identity in Foreign Language Learning and Teaching: Why Listen to our Students' and Teachers' Voices Really Matters.' ELT Research Papers 13-02, London, British Council, University of York.

Torrance, TF 1965. Theology in Reconstruction. Grand Rapids: WB Eerdmans Publishing Company.

Vale, P 2016. 'Say it in Plain (African Language: Education Plus Courses, Seminars \& Bursaries.' Mail \& Guardian, January 8 to 14, 2016.

Woodhead, L 1998. 'Teaching Theology as a Foreign Language.' Volume 1, Issue 1, Article first published online: 10 Jan 2003. Lancaster, Blackwell Publishers.

Woolard, KA, Schieffelin, BB 1994. 'Language Ideology'. Annual Review of Anthropology 23 (1): 55-82. doi:10.1146/annurev.an.23.100194.000415. 